\title{
ENSURING A POSITIVE ORGANIZATIONAL CLIMATE - A MANDATORY PERFORMANCE CRITERION
}

\author{
Solomia ANDREȘ ${ }^{a}$, Suzana DEMYEN ${ }^{*}$ \\ a Babeș- Bolyai University, Faculty of Economics and Business Administration, Romania \\ ${ }^{b}$ UBB University Center of Resita, Romania
}

DOI: $10.24818 / \mathrm{IMC} / 2020 / 04.05$

\begin{abstract}
Performance is the most important objective of an enterprise, regardless of the type of enterprise or whether it can be quantified or not. The main issue that any company needs to focus on is how to achieve a high level of performance. Organizational culture acquires a very important role from this point of view, respectively the positive character of the climate, both aspects being considered indispensable for the obtaining of a good work result. This article offers a brief theoretical outline of the main ideas on the importance of culture for an organization, and the second part presents the results of a study on employee perception of the positive nature of the organizational climate in the entities employees operate in.
\end{abstract}

KEYWORDS: behavior, employees, objectives, organizational culture, performance.

\section{INTRODUCTION}

The level of organizational efficiency is the result of multiple influences, quantitative and qualitative, quantifiable or not. The Hofstede Insights (2018) report differentiate this aspect through a double approach, identifying two types of cultures: a culture oriented towards "means", where the mode of action matters the most, respectively a culture oriented towards objectives, where results prevail.

Among the influences mentioned, specialty studies mention the importance that organizational culture acquires among this conglomeration of factors. In turn, organizational culture is influenced by both internal and external elements: the management style practiced, the clarity of the decision making process, leadership power, ensuring the resources necessary for proper business management at the organizational level, the objectivity of the evaluation system, system diversity motivation (Matko \& Takacs, 2017), values promoted at a general level (Stok et al., 2010), compatibility between employees and positions held, etc.

Other debates on the conceptual difference between the notion of "organizational culture” and „organizational climate” can also be observed. Some authors, Denison (2000) thus state that the difference between the two terms can be justified in terms of perception, context and approach. Thus, an inclusive link between the two concepts can't be established, being rather the reflection of some characteristics that depend on individual interpretation and perception of values promoted at an organizational level and the response to the actions of environmental factors. Literature (Sull et al., 2019) presents ideas according to which "most large companies describe their organizational culture in terms of the values desirable to be practiced by employees".

However, achieving individual and organizational goals is closely related to both leadership (Andreș, 2006a; Szczepanska-Wodzczyna, 2015) and employee self-management (Rousseau, 1997), together with the importance of teamwork, which cannot be ignored (Andreș, 2006b).

\footnotetext{
* Corresponding author, e-mail: suzana_demyen@yahoo.com
} 


\section{THEORETICAL BACKGROUND}

Ensuring a positive organizational climate that encourages both the effective collaboration of team members, but also contributes in creating and maintaining a high level of motivation at the organizational level becomes essential the achievement of organizational performance.

Regardless of the way in which the organizational culture is defined, either from the result perspective or from the instrument perspective (Hofstede, 1993; Schein, 1992), the values promoted at an organizational level (Demyen \& Corneanu, 2019) turn into a characterization element of the organization personality, in a sufficiently complex context, which justifies the identification of a logical link between the need to implement a positive approach and the required performance criterion.

Kaifi and Noori (2011) propose a RED (Recognize - Explain - Develop) approach, in order to perform an objective analysis and understanding of organizational behavior aspects.

One cannot ignore the fact that we live in a dynamic and ever-changing world. Not only people are subject to changes imposed by the time factor; enterprises, in their turn, act and react from multiple perspectives, their way of reaction depending largely on the strength of their organizational culture. The attitude towards change can also be analyzed in terms of the type of culture found within the organization, idea sustained by Gambi et al. (2013), who underline four types of culture: group culture, development-oriented culture, culture based on hierarchical dimensions, culture based on reason. Consequently, the level of adaptability and flexibility depends largely on the type of culture that characterizes the organization (Bretcu \& Demyen, 2018). Yesil and Kaya (2013) also mention the link between the type of culture practiced and performance.

The human factor confirms the importance of the organizational culture role in terms of organizational behavior, the connection of this discipline with anthropology being important to be underlined in this case. Bauer and Erdogan (2012) tried to answer the question "What is organizational behavior?". They defined this concept as "the way individuals and groups act within organizations" and justified its importance from three points of view:

- of employees - as a creator of more involved members within the organization;

- of employers - as a centralizer of those qualities or skills that are most desired (communication, integrity, collaboration, initiative, work ethic);

- of the organization - understanding that the appreciation of all employees is much more profitable than the opposite alternative.

A summary of ideas underlined by classical definitions results in the following representation:

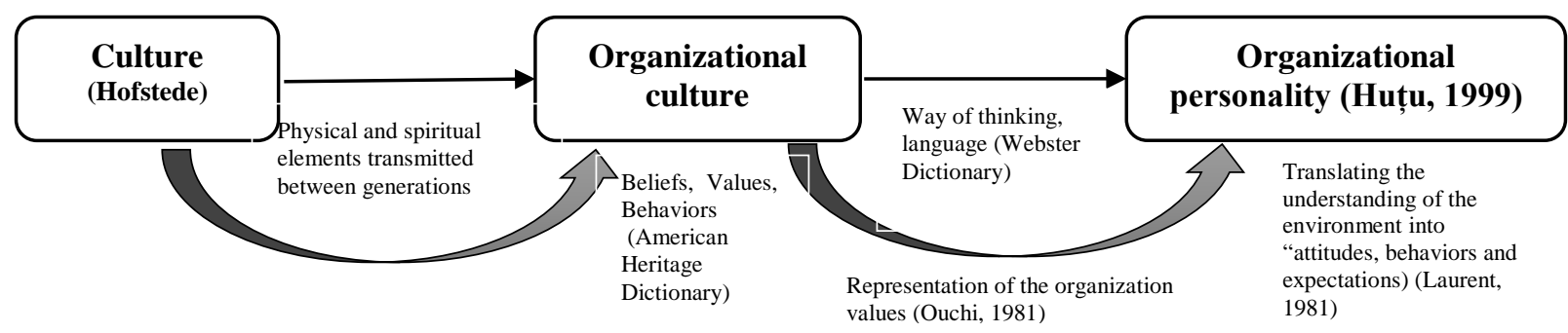

Figure 1. The relationship between theoretical concepts

Source: author's processing of information retrieved from references

Starting from these statements, the following axioms were identified for this paper:

A1 - organizational culture is very important for all organizations, regardless of size;

A2 - the organization individual values largely reflect the values of the national culture these belong to; 
A3 - organizational culture greatly influences the performance of organizations.

Consequently, the following hypotheses were formulated, to be verified in the study presented:

$\mathrm{H} 1$ - a positive organizational climate is essential for achieving performance at the organizational level;

$\mathrm{H} 2$ - conflicts within an organization can serve both as a constructive element and as a destructive one;

H3 - the employees' perception of teamwork is different, depending on each individual, one's personality and attitude towards work showing significant influences in this regard.

\section{STUDY ON THE IMPORTANCE OF A POSITIVE CHARACTER OF ORGANIZATIONAL CULTURE FOR THE PERFORMANCE OF HUMAN RESOURCES}

\subsection{Research methodology}

In order to study the issue proposed at the beginning of this article, from an applicative point of view, an analysis on the importance of the organizational culture pillars for human resource performance, as perceived by employees, was conducted. The present research has as a starting point the results obtained in other previous studies prepared by authors on related topics (Ciurea \& Demyen, 2019; Demyen \& Corneanu, 2019), in which specific limits have been identified, but which offered perspectives to continue the research. In general, these limits were imposed either by the small sample of respondents or by an insufficient development of the subject.

The research included an online questionnaire, applied with the help of a form written in Microsoft Forms. This method of application was mainly imposed by the current context, generated by the presence of SarsCov2 virus, which imposed the limitation of physical contacts, the questionnaire being administered between April and June 2020. The sample consisted of 190 people, residents of Resita, of which $61 \%$ are females, and 39\% - males. Regarding the distribution of respondents by age groups, the structure of the sample is shown in the graph below.

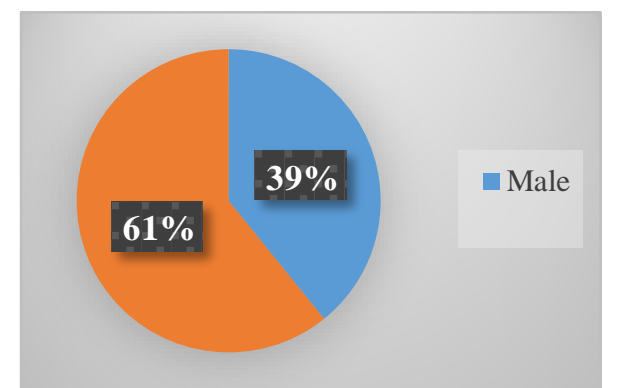

Figure 2. Sample structure on gender Source: realized by the authors

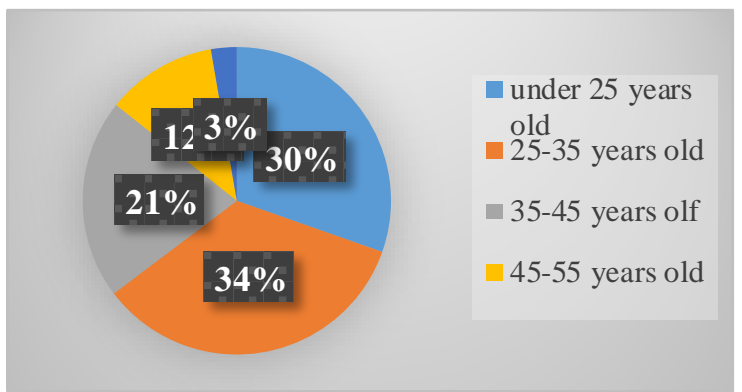

Figure 3. Sample structure of age groups Source: realized by the authors

$80.1 \%$ of the respondents were with executive positions; while $19.90 \%$ hold management positions, the fields in which they operate being: industry, trade, services, tourism, transport, construction, gastronomy, education.

The structure of the online questionnaire consisted of two parts, represented by 13 content questions and 4 identification questions.

The main objective of the research was: the analysis of the respondents' perception regarding the need to ensure a positive organizational climate, in order to ensure an optimal level of performance within the organization.

The secondary objectives consisted of:

1. identifying the level of respondents' familiarity with the concept of organizational culture;

2. identifying the level of correspondence between individual and organizational objectives; 
3. identifying the main aspects that can be improved in the workplace to ensure a higher level of efficiency;

4. the respondents' appreciation of the current level of organizational climate positivity;

5. identifying the factors considered important for a performance-generating organizational culture;

6. identification the extents in which employees have the opportunity to participate in training, qualification, professional development activities;

7. identifying the respondents' attitude towards the organizational conflict;

8. identifying the respondents' attitude regarding teamwork and inter-relationship between employees. As a sequel of previous research, the secondary objectives no. 2, 6, 7 were proposed, in order to deepen the conclusions of previous studies, on a larger sample of respondents.

\subsection{Analysis of study results and research conclusions}

Following the centralization of the results, the following conclusions regarding the proposed objectives were obtained:

On the level of familiarity with the notion of organizational culture, the respondents proved an average knowledge of this term. Only $48 \%$ of respondents say they are familiar with this concept to a large or very large extent, while $41 \%$ indicate an average level of familiarity.

Regarding the correspondence between individual and organizational objectives, most of the respondents identified at an average level with the organization, their objectives coinciding with those of the company, which proves that there is no strong sense of belonging to the organization. The results obtained are very close to the conclusions of the previous study, although, this time, the volume of the analyzed sample is almost four times higher than the initial one. And this time, the percentage value calculated for the coefficient of variation indicates a high level of representativeness, with $\mathrm{V}=27.73 \%$ (according to Table 1 ).

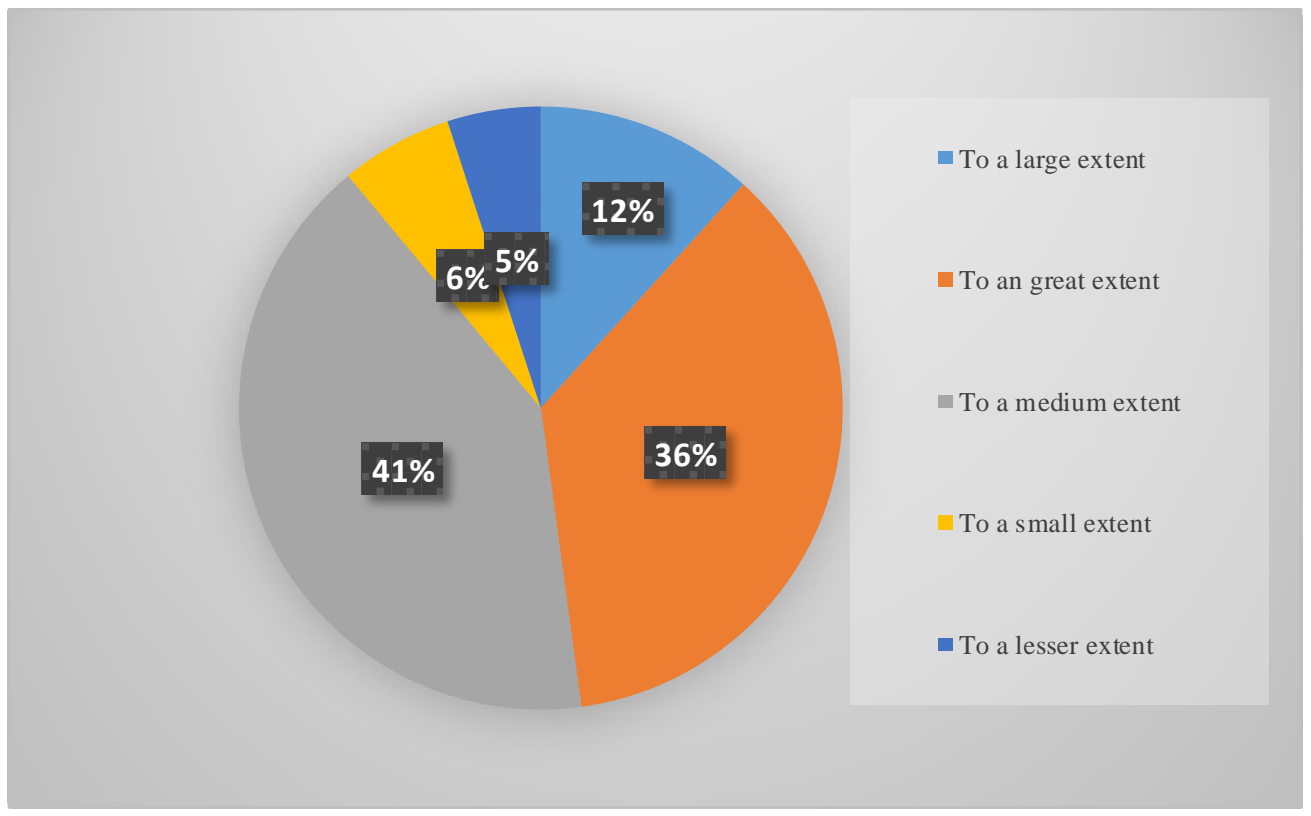

Figure 4. Level of familiarity with the concept of organizational culture Source: realized by the authors

The level of representativeness of the studied sample was verified by calculating the statistical indicators; in this case it presented a high level of representativeness, analyzed through the coefficient of variation, for which a percentage value of $27.90 \%$ was determined. (Table 1) 


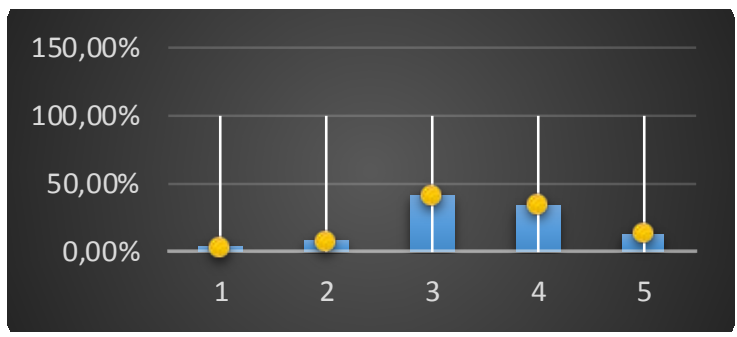

Figure 5. Correspondence between personal goals and organizational goals Source: realized by the authors

This confirms the answers provided by respondents, of which $41.1 \%$ consider that there is an average level of correspondence between individual and organizational objectives, offering a 3 value. However, the percentages of respondents who identify a high level of correspondence between organizational objectives and theirs is as follows: $34.40 \%$ of the respondents therefore offer a 4 value to this aspect, while $13.3 \%$ of the respondents state a maximum level of correspondence between objectives.

Certainly, no organization is characterized only by positive aspects; there are also elements that need to be improved. Aspects included in the category of those that need development in the workplace, for a higher level of efficiency, and mentioned were: the teamwork quality (mentioned by $36.5 \%$ of respondents), communication with colleagues and management (identified by a percentage of $32.6 \%$ as problematic), the possibilities of professional development (31.5\%), the process of human resources motivating (29.2\%), respectively the level of colleagues' involvement in the work performed (28.1\%).

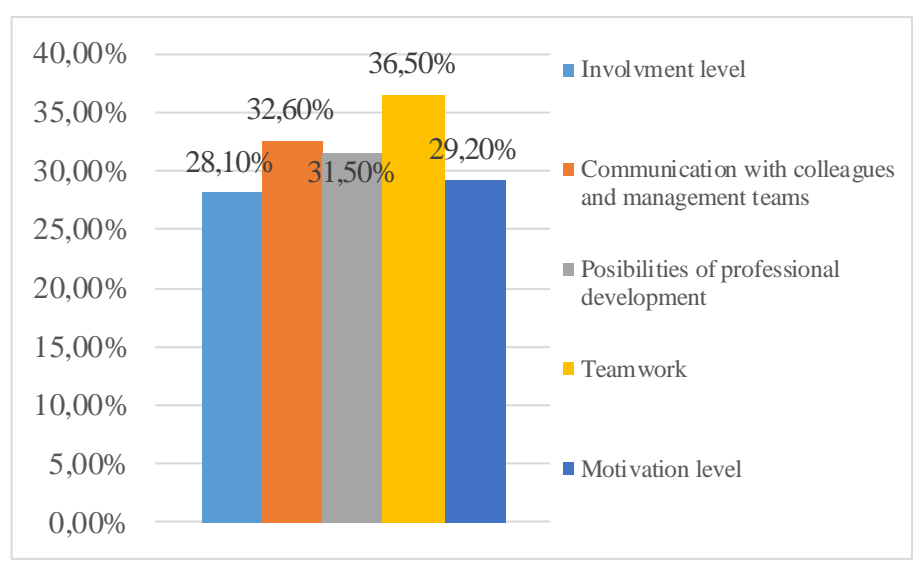

Figure 6. Element needing improvement Source: realized by the authors

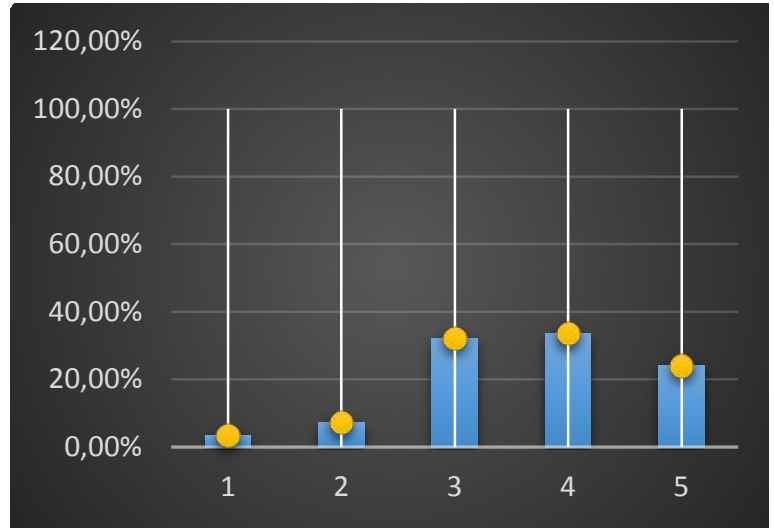

Figure 7. Positive character of organizational culture

Source: realized by the authors

To support these results, the positive character of the organizational culture in the enterprises in which the respondents operate was also analyzed. To assess this characteristic, respondents marked levels from 1 to 5, using the Likert scale; the conclusions obtained being the following: more than half of the respondents (57.3\%) appreciate the organizational culture of the enterprises in which they work as a positive one, choosing a 4 or 5 levels. A lower percentage, 32.2\%, indicates an average level of satisfaction with this criterion, and $10.5 \%$ represents the percentage of employees dissatisfied with this aspect. The verification of the homogeneity level of the sample indicates a 
coefficient of variation equal to $27.7 \%$; therefore, the sample of respondents was representative for this research.

The positive character of organizational culture is considered to be directly related to the level of performance achieved by employees, but, naturally, in this case some determining factors could also be identified.

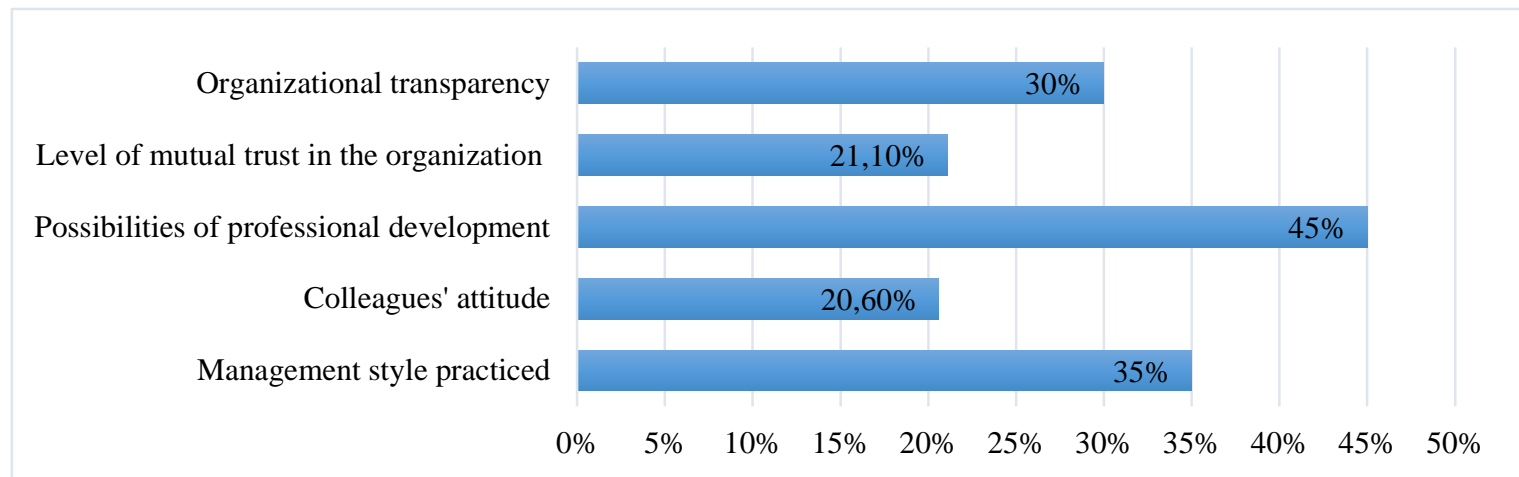

Figure 8. Performance determinate factors

Source: realized by the authors

Transparency of processes within the organization is considered by employees a relevant factor, being indicated by $30 \%$ of respondents. However, elements such as the level of mutual trust within the organization, considered important by $21.10 \%$ of respondents, respectively the attitude of colleagues, this being indicated as a factor influencing performance by $20.60 \%$ of those surveyed. It is recognized that a positive, open, friendly attitude, as well as a behavior that promotes mutual respect between colleagues, will also generate a much more fruitful collaboration, the orientation towards results being real, and the level of performance achieved - much higher.

A different picture, representing a team in which conflicts predominate, will not be able to encourage and promote performance. Unfortunately, in a very competitive society, where not all organizations have the opportunity to offer equitable prospects of promotion and professional development, colleagues often become rivals, the pursuit of individual rewards often overshadowing team performance.

These aspects lead to the conclusion that the existence of a strong team, while ensuring a transparent management, is the basis for achieving performance at the organizational level. However, the management attitude will always be reflected in the work realized by subordinates, the management style practiced can greatly boost or, conversely, can reduce the dedication, effort, motivation and performance of employees.

This aspect is mentioned by $35 \%$ of respondents. But, as an essential and at the same time important motivating element of the quality of the work performed, the existence of professional development opportunities is a determining factor of individual performance for almost half of the employees (45\%).

In connection with this aspect, it is important to note the extent to which employees actually have access to such professional development actions. From the research conducted, one can see, related to the possibility to participate in training, qualification or professional development activities, that $23 \%$ of respondents have access to it to a very large extent, $25 \%$ have access to a great extent, while $35 \%$ can benefit of such actions only occasionally.

The calculation of the statistical indicators regarding the verification of the level of representativeness indicates a percentage value of $32.17 \%$ for the variation coefficient. 


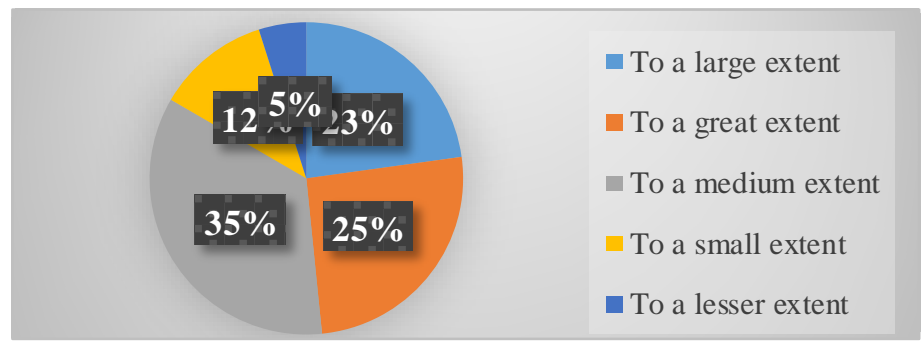

Figure 9. Access to professional development actions

Source: realized by the authors

This is a higher level than the one in the previous situations, which indicates a relative homogeneity, partly due to the fact that the respondents belong to different fields of activity, which offer opportunities for professional development in a different way. The result also depends on the level of the position held (management or execution), respectively on the age of the respondents.

There are few organizations that are completely conflict-free. Their number is very small, moving more towards the idea of utopia, if one takes into account the Time factor. The number, frequency, typology and intensity of conflicts largely depend on the size of the organization, with differences between micro, small, medium or large enterprises. Regarding the frequency of conflicts, $60 \%$ of the respondents of this study consider that these occur rarely in the organizations in which they work, $7 \%$ admit a very high frequency of conflicts, and $25 \%$ indicate a high frequency, while only $8 \%$ state that situations of a conflicting nature never occur.

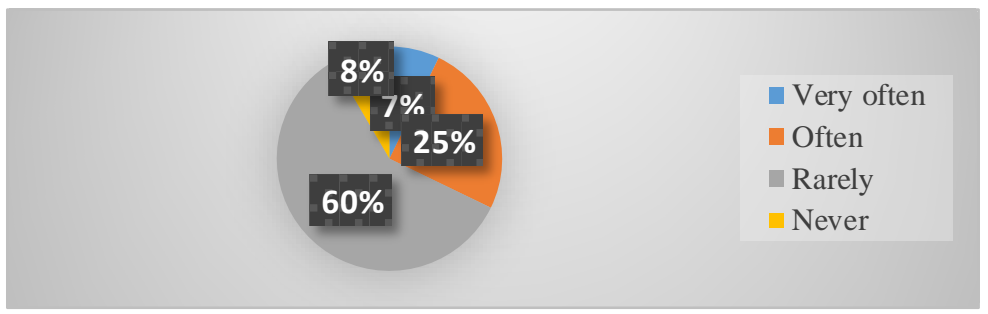

Figure 10. Frequency of conflicts in the organization Source: realized by the authors

Even if the percentage of $8 \%$ of respondents, who declare the absence of conflicts in the organization, seems quite high at first sight, the statistical verification leads to the identification of a high degree of representativeness, by the value of the coefficient of variation, calculated as $26.89 \%$, which reflects a high level of homogeneity of the sample studied.

In the case of employees who, however, recall conflicts as being present to a greater or lesser extent in the organizations in which they work, the main causes identified were the following:

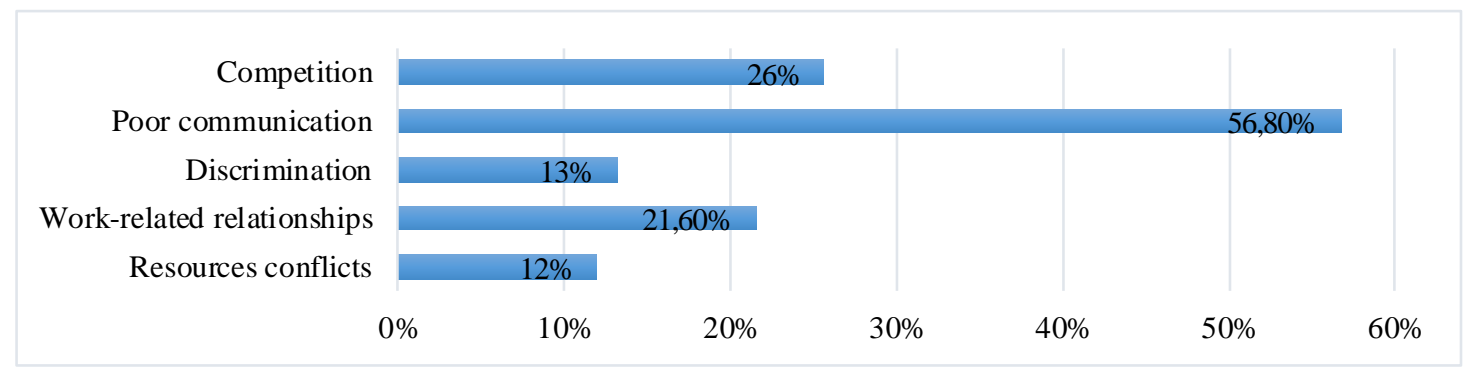

Figure 11. The most common causes of conflict

Source: realized by the authors 
There are numerous reasons that can lead to multiple conflicts. The intergenerational ones are not foreign to Romanian organizations: differences of opinion, different mentalities, perception, motivation, etc. between employees of different ages or belonging to different generations. The attitude towards work is different, the individuals' talents, skills, abilities often generating even tensions between employees. Regarding the intensity of intergenerational conflicts, between employees, the respondents' answers show that these are generally of medium intensity, at a 3 level, given by most respondents, on a scale from 1 to 5 .

Regarding the quality of communication and collaboration between members of the organization, respondents rate these issues as at least average level, most answers indicating an average score of 3 , but very close to the answers of those who believe that in the organization, communication it is a good one, the score given being 4 , on a scale of 5 units.

Mutual trust is very important for team members, being an indirect determinant of group performance, while communication and collaboration are a direct factor. This criterion is positively evaluated by the respondents, who assign at least an average level, the 3rd level being predominant in the evaluation scale, but present to a large extent are also good and very good evaluations, levels 4 and 5 being also found in the assessments made by the individuals surveyed.

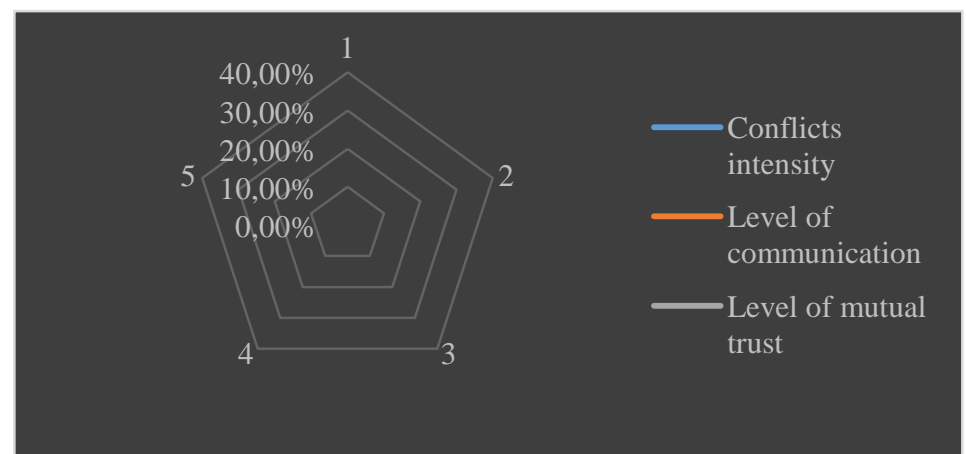

Figure 12. Conflict intensity, level of communication and mutual trust

Source: realized by the authors

The advantages of teamwork are recognized by the respondents in the sample. Thus, $56 \%$ of those surveyed say that teamwork is very important for individual and group performance, $28 \%$ share this opinion giving a very close rating, the equivalent of 4th level on the Likert scale. Only $12 \%$ acknowledge an average importance, while $4 \%$ partially or totally deny the importance of this aspect.

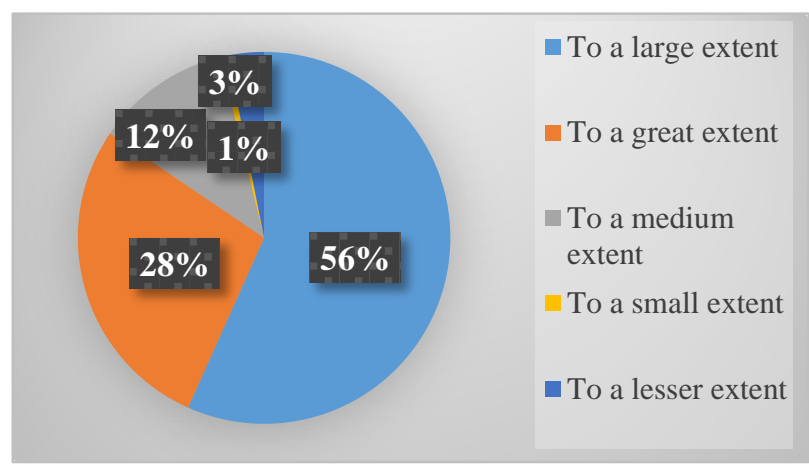

Figure 13. Importance of teamwork

Source: realized by the authors

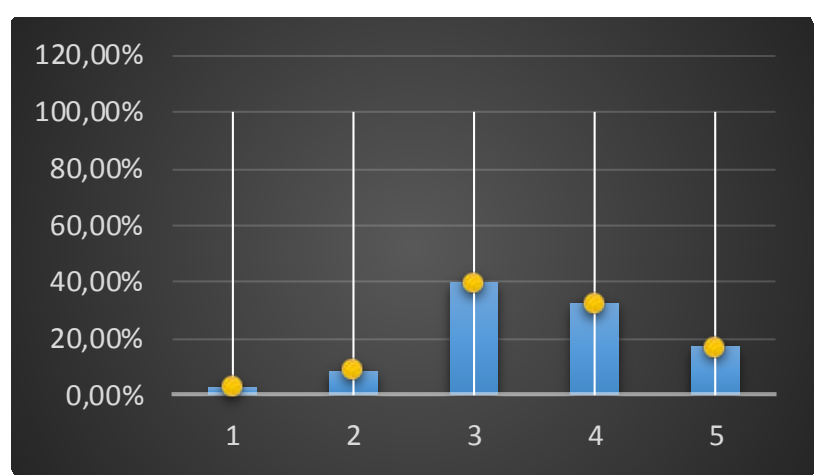

Figure 14. Organization level of equity Source: realized by the authors 
The fairness of all actions carried out within an organization is of particular importance, regardless of the field of activity, the size of the company or the financial results obtained. It is vital that all employees receive all the advantages or benefits of the job correctly and without discrimination, and that tasks and responsibilities are distributed fairly and impartially. This aspect was left to be analyzed at the end of the study, the results obtained indicating the following: approximately $40 \%$ of respondents identify an average level of equity in the policies promoted by the organization in which they operate. The remaining $60 \%$ is at the two limits, namely: about $12.1 \%$ of employees consider the level of equity is low or very low, while more than $47.9 \%$ identify a high and even very high level. $65 \%$ of respondents say they have not encountered any ethical issues at work.

\subsection{Verification of results}

Regarding the level of representativeness of the sample of respondents, as well as of the answers provided by them, a summary of the results and the calculations performed for the criteria explained above has been realized. Each initially objective established has as correspondent at least one of these criteria, the degree of homogeneity being determined by the following statistical indicators: arithmetic mean average, dispersion, quadratic mean deviation, respectively the coefficient of variation.

Table 1. Statistical verification of study results

\begin{tabular}{|l|c|c|c|c|c|c|c|c|}
\hline \multicolumn{1}{|c|}{ Criterion } & $\begin{array}{c}\text { Correspondin } \\
\text { g objective }\end{array}$ & $\mathbf{N}$ & $\begin{array}{c}\text { Mi } \\
\mathbf{n}\end{array}$ & $\begin{array}{c}\text { Ma } \\
\mathbf{x}\end{array}$ & $\begin{array}{c}\text { Arithmetic } \\
\text { mean } \\
\text { average }\end{array}$ & Dispersion & $\begin{array}{c}\text { Quadratic } \\
\text { mean } \\
\text { deviation }\end{array}$ & $\begin{array}{c}\text { Coefficien } \\
\text { t of } \\
\text { variation }\end{array}$ \\
\hline $\begin{array}{l}\text { Level of familiarity with } \\
\text { the concept of } \\
\text { "organizational culture" }\end{array}$ & $\mathbf{O S ~ 1}$ & 190 & 1 & 5 & 3,4368 & 0,9196 & 0,9590 & $27,90 \%$ \\
\hline $\begin{array}{l}\text { The level of } \\
\text { correspondence between } \\
\text { individual and } \\
\text { organizational } \\
\text { objectives }\end{array}$ & $\mathbf{O S ~ 2}$ & 190 & 1 & 5 & 3,4631 & 0,9223 & 0,9603 & $27,73 \%$ \\
\hline $\begin{array}{l}\text { The current level of } \\
\text { positivity of the } \\
\text { organizational climate }\end{array}$ & $\mathbf{O S ~ 4}$ & 190 & 1 & 5 & 3,6789 & 1,0390 & 1,0193 & $27,70 \%$ \\
\hline $\begin{array}{l}\text { The extent to which } \\
\text { employees have the } \\
\text { opportunity to } \\
\text { participate in training, } \\
\text { qualification, } \\
\text { professional } \\
\text { development activities }\end{array}$ & $\mathbf{O S ~ 6}$ & 190 & 1 & 5 & 3,4894 & 1,2604 & 1,1226 & $32,17 \%$ \\
\hline Frequency of conflicts & $\mathbf{O S ~ 7}$ & 190 & 1 & 5 & 2,6842 & 0,5213 & 0,7220 & $26,89 \%$ \\
\hline $\begin{array}{l}\text { The level and intensity } \\
\text { of intergenerational } \\
\text { conflicts }\end{array}$ & $\mathbf{O S ~ 8}$ & 190 & 1 & 5 & 1,9947 & 1,3040 & 1,1419 & $57,24 \%$ \\
\hline $\begin{array}{l}\text { Communication and } \\
\text { collaboration between } \\
\text { members of the } \\
\text { organization }\end{array}$ & $\mathbf{O S ~ 8}$ & 190 & 1 & 5 & 2,0947 & 1,6223 & 1,2737 & $60,80 \%$ \\
\hline $\begin{array}{l}\text { The level of mutual trust } \\
\text { between employees }\end{array}$ & $\mathbf{O S ~ 8}$ & 190 & 1 & 5 & 2,3315 & 1,6601 & 1,2884 & $55,26 \%$ \\
\hline Importance of teamwork & $\mathbf{O S ~ 8}$ & 190 & 1 & 5 & 3,2263 & 1,8609 & 1,3641 & $42,28 \%$ \\
\hline $\begin{array}{l}\text { Level of equity in the } \\
\text { organizational policies }\end{array}$ & $\mathbf{O S ~ 4}$ & 190 & 1 & 5 & 2,2421 & 1,5277 & 1,2360 & $55,12 \%$ \\
\hline
\end{tabular}

Source: calculation realized by the authors 
In order to study the degree of association of the variables considered essential for building a positive organizational culture, we used the Pearson correlation coefficient presented below. Knowing that the range of variation of the Pearson correlation coefficient is between $r=-1$ (negative perfect correlation) and $r=+1$ (positive perfect correlation), the following correlation matrix was obtained, where the correlations between the pairs of variables are illustrated.

Table 2. Pearson correlation

\begin{tabular}{|c|c|c|c|c|c|c|c|c|}
\hline & & $\begin{array}{c}\text { Personal and } \\
\text { organizational } \\
\text { goal } \\
\text { correspondence }\end{array}$ & $\begin{array}{c}\text { Positive } \\
\text { Organizational } \\
\text { culture }\end{array}$ & $\begin{array}{c}\text { Access to } \\
\text { professional } \\
\text { development }\end{array}$ & $\begin{array}{l}\text { Conflict } \\
\text { frequency }\end{array}$ & Communication & $\begin{array}{c}\text { Level } \\
\text { of } \\
\text { trust }\end{array}$ & Teamwork \\
\hline \multirow{3}{*}{$\begin{array}{l}\text { Personal and } \\
\text { organizational } \\
\text { goal } \\
\text { correspondence }\end{array}$} & $\begin{array}{l}\text { Pearson } \\
\text { Correlation }\end{array}$ & 1 &, $915^{* *}$ &, $942^{* *}$ &, $826^{* *}$ &, $964^{* *}$ &, $944^{* *}$ & ,848 \\
\hline & $\begin{array}{l}\text { Sig. (2- } \\
\text { tailed) }\end{array}$ & & ,000 & ,000 & 000 & ,000 & 000 & ,000 \\
\hline & $\mathrm{N}$ & 190 & 190 & 190 & 190 & 190 & 190 & 190 \\
\hline \multirow{3}{*}{$\begin{array}{l}\text { Positive } \\
\text { Organizational } \\
\text { culture }\end{array}$} & $\begin{array}{l}\text { Pearson } \\
\text { Correlation }\end{array}$ &, $915^{* *}$ & 1 &, $938^{* *}$ &, $835^{* *}$ & ,907** & ,920** & ,886** \\
\hline & $\begin{array}{l}\text { Sig. (2- } \\
\text { tailed) }\end{array}$ & ,000 & & ,000 & 000 & ,000 & 000 & 000 \\
\hline & $\mathrm{N}$ & 190 & 190 & 190 & 190 & 190 & 190 & 190 \\
\hline \multirow{3}{*}{$\begin{array}{l}\text { Access to } \\
\text { professional } \\
\text { development }\end{array}$} & $\begin{array}{l}\text { Pearson } \\
\text { Correlation }\end{array}$ &, $942^{* *}$ &, $938^{* *}$ & 1 &, $814^{* *}$ &, $963^{* *}$ &, $976^{* *}$ &, $870^{* *}$ \\
\hline & $\begin{array}{l}\text { Sig. (2- } \\
\text { tailed) }\end{array}$ & ,000 & ,000 & & ,000 & ,000 & ,000 & ,000 \\
\hline & $\mathrm{N}$ & 190 & 190 & 190 & 190 & 190 & 190 & 190 \\
\hline \multirow[t]{3}{*}{$\begin{array}{l}\text { Conflict } \\
\text { frequency }\end{array}$} & $\begin{array}{l}\text { Pearson } \\
\text { Correlation }\end{array}$ &, $826^{* *}$ &, $835^{* *}$ &, $814^{* *}$ & 1 &, $840^{* *}$ &, $828^{* *}$ & ,828** \\
\hline & $\begin{array}{l}\text { Sig. (2- } \\
\text { tailed) }\end{array}$ & ,000 & ,000 & ,000 & & ,000 & 000 & 000 \\
\hline & $\mathrm{N}$ & 190 & 190 & 190 & 190 & 190 & 190 & 190 \\
\hline \multirow[t]{3}{*}{ Communication } & $\begin{array}{l}\text { Pearson } \\
\text { Correlation }\end{array}$ &, $964^{* *}$ &, $907^{* *}$ &, $963^{* * *}$ &, $840^{* *}$ & 1 & ,972** & ,872** \\
\hline & $\begin{array}{l}\text { Sig. (2- } \\
\text { tailed) }\end{array}$ & ,000 & ,000 & ,000 & ,000 & & ,000 & ,000 \\
\hline & $\mathrm{N}$ & 190 & 190 & 190 & 190 & 190 & 190 & 190 \\
\hline \multirow[t]{3}{*}{ Level of trust } & $\begin{array}{l}\text { Pearson } \\
\text { Correlation }\end{array}$ & ,944** & ,920** &, $976^{* *}$ &, $828^{* *}$ &, $972^{* *}$ & 1 & ,862 $2^{* *}$ \\
\hline & $\begin{array}{l}\text { Sig. (2- } \\
\text { tailed) }\end{array}$ & ,000 & ,000 & ,000 & ,000 & ,000 & & ,000 \\
\hline & $\mathrm{N}$ & 190 & 190 & 190 & 190 & 190 & 190 & 190 \\
\hline
\end{tabular}




\begin{tabular}{|c|c|c|c|c|c|c|c|c|}
\hline & & $\begin{array}{c}\text { Personal and } \\
\text { organizational } \\
\text { goal } \\
\text { correspondence }\end{array}$ & $\begin{array}{c}\text { Positive } \\
\text { Organizational } \\
\text { culture }\end{array}$ & $\begin{array}{c}\text { Access to } \\
\text { professional } \\
\text { development }\end{array}$ & $\begin{array}{l}\text { Conflict } \\
\text { frequency }\end{array}$ & Communication & $\begin{array}{l}\text { Level } \\
\text { of } \\
\text { trust }\end{array}$ & Teamwork \\
\hline \multirow[t]{4}{*}{ Teamwork } & Pearson &, $848^{* *}$ &, $886^{* *}$ &, $870^{* *}$ &, $828^{* *}$ &, $872^{* *}$ &, $862^{* *}$ & 1 \\
\hline & Correlation & & & & & & & \\
\hline & $\begin{array}{l}\text { Sig. (2- } \\
\text { tailed) }\end{array}$ & ,000 & ,000 & ,000 & ,000 & ,000 & ,000 & \\
\hline & $\mathrm{N}$ & 190 & 190 & 190 & 190 & 190 & 190 & 190 \\
\hline
\end{tabular}

Source: computation made by the authors

We notice that a variable correlated with itself is perfectly positive $(r=1)$. All variables have positive correlations and a high degree of significance, p being less than 0.001 . In the case presented above, the highest degree of significance of the correlation can be observed between the variable "access to professional development programs" and the variable "mutual trust" (.976). Interestingly, however, even the lowest level of significance of the correlations also implies the variable "mutual trust", but analyzed this time in relation to the frequency of conflicts, which gives us, by extrapolation, valuable information on the real level of equity in organization, also confirming the value of $55.12 \%$ previously obtained by calculating the coefficient of variation (which indicates a relative level of homogeneity of respondents' responses).

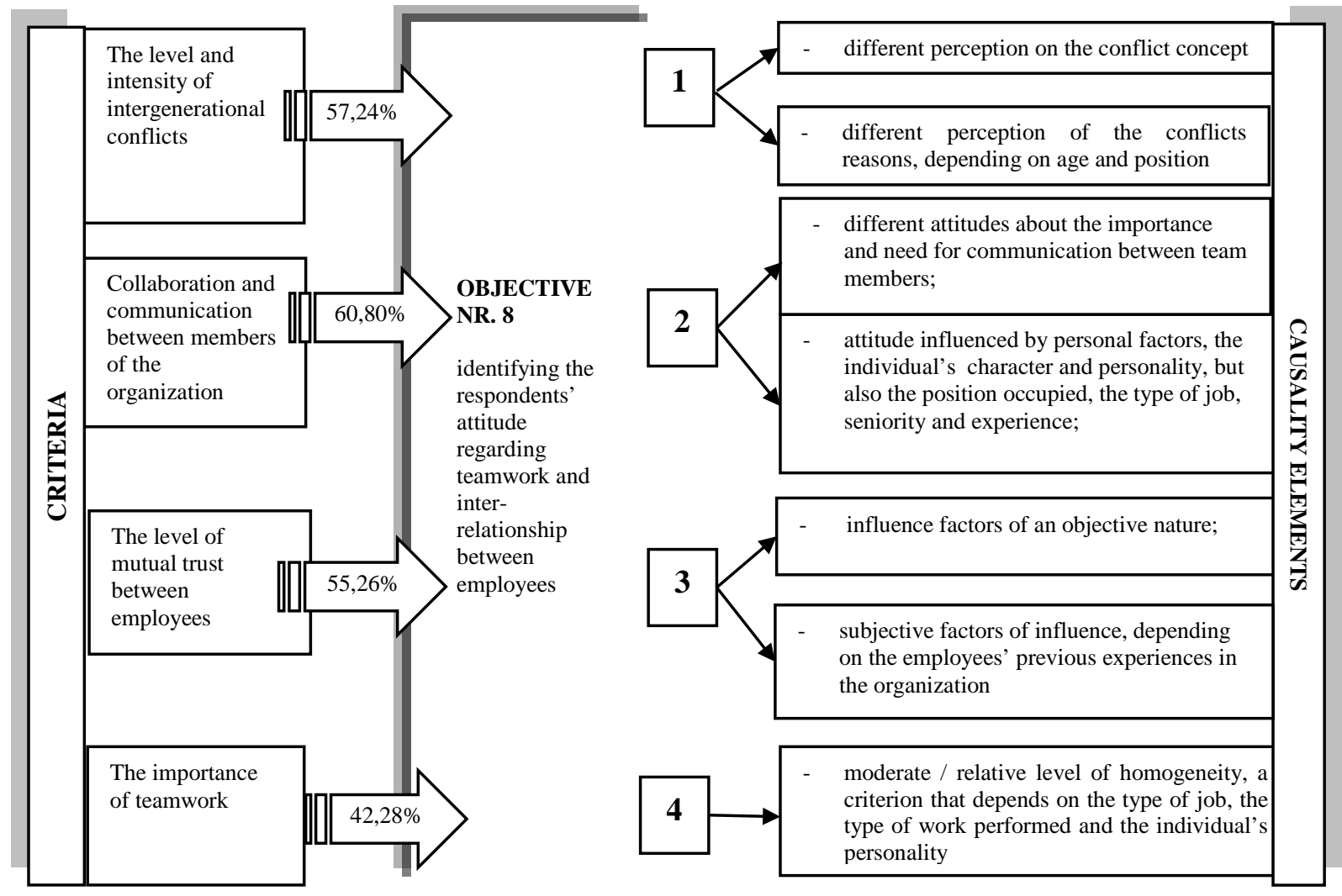

Figure 15

Source: realized by the authors

As mentioned above, most of the criteria in the table 1 have registered at least a moderate level of homogeneity; however, there are cases where the influence of external factors causes differences in 
responses. The representativeness of the answers provided by the respondents is therefore verified for the criteria corresponding to objectives $1,2,6,7$, partially for objective 4 , registering cases of heterogeneity for objective no. 8 - identifying the respondents' attitude regarding teamwork and inter-relationship between employees.

The cases in which the level of representativeness is lower are due to the different perceptions of respondents, regarding the criteria subjected to analysis. The employees' attitudes regarding the importance of teamwork, respectively the relationships between colleagues are largely subject to analysis in the light of previous experiences. To these, the different perceptions of respondents, are added, depending on their age, position, type of position - management or execution, seniority, etc. The attitude towards communication is also influenced by personal factors, the individual's character and personality, which leads to obtaining values of over $40 \%$ for the coefficient of variation.

\section{CONCLUSIONS}

The importance of organizational culture is presented in many specialty papers, but the "contemporaneity" of the topic is justified, given the factor "change". As mentioned at the beginning of this paper, organizations are dynamic, subject to change, but beyond a „technical” explanation from this point of view, it is essential to take into consideration the human factor.

As a conclusion of the study, in general, the employee's perception of the organizational climate within the companies in which they operate is largely similar, as evidenced by the results obtained during the statistical verification phase. Views on a positive culture are thus identified, which have the potential to generate performance, even if the main issue identified remains that of teamwork. Even if employees do not share the same opinion on its importance, or they are not used to working as a team, or the roles in the organization are not clearly delimited, the conclusion is still that this aspect requires increased attention from the management teams.

Each generation is different from the previous ones, both in terms of skills, competencies, and especially in terms of individual behavior, values, principles and level of flexibility in service issues. Rapid advances in technology require increasing adaptability to the organization, but employees are primarily subject to environmental influences, because individual or team actions are reflected in terms of performance.

Although from a statistical point of view, most of the hypotheses proposed at the beginning of the study are confirmed by the calculated indicators, we can say that the sample of 190 people who responded to the research is not enough to generalize the conclusions. We propose to restrict these limits by conducting parallel studies in different fields. Also, the results presented in this paper are only conclusions obtained at the level of enterprises in a single city.

Also, as proposed by Cizmaș et al. (2020), we consider it necessary to study at individual level the correlation between variables, by work teams, respectively complete organizations.

The criteria underlined in the presented study can be analyzed over several time intervals, being possible to draw comparisons between generations, in order to create a parallel presentation of their attitude towards:

- the importance of ensuring a positive organizational climate;

- the importance of teamwork and the perception of its benefits;

- factors that determine performance at the organizational level.

We appreciate that all these results can be the premises for the identification of perspectives for the study continuity, aiming to focus future studies on the representatives of Generation Z, respectively on a comparison between perspectives on teamwork and influences on organizational culture. 


\section{REFERENCES}

Andreş, S. (2006a). Evaluarea şi perfecţionarea stilului de management în instituţiile financiare. Timişoara: Mirton Publishing.

Andreş, S (2006b). Managementul participativ - cale de creştere a eficacităţii conducerii şi eficienţei activităţii organizaţiei. Timişoara: Mirton Publishing.

Bauer, T. \& Erdogan, B. (2012). An introduction to organizational behavior. Boston: Flat World.

Bretcu, A. \& Demyen, S. (2018). Total Quality Management and the Collaborative Adhocracy. Annals of Faculty of Economics, University of Oradea, Faculty of Economics, 1, 402-422.

Ciurea, J. \& Demyen, S. (2019). The employee perception on the importance of organizational culture for the future of an enterprise. Annals of the „Constantin Brâncuși” University of Târgu Jiu, Economy Series, 3, 237-244.

Cizmaş, E., Feder, E. S., Maticiuc, M. D. \& Vlad-Anghel, S. (2020). Team management, diversity, and performance as key influencing factors of organizational sustainable performance. Sustainability, 12(18), 7414. doi: 10.3390/su12187414.

Demyen, S. \& Corneanu-Lipou, L. R. (2019). The importance of organizational values and the capabilities of managers for the performance of an enterprise. Annals of the „Constantin Brâncuși”, University of Târgu Jiu, Economy Series, 4, 30-38.

Denison, D. R. (2000). Organizational culture: Can it be a key lever for driving organizational change? In S. Cartwright \& C. Cooper (Eds.), The handbook of organizational culture. London: JohnWiley \& Sons.

Gambi, L. N., Gerolamo, M. C. \& Carpinetti, L. C. R. (2013). A theoretical model of the relationship between organizational culture and quality management techniques. Procedia Social and Behavioral Sciences, 81, 334-339.

Hofstede, G. (1993). Cultural constraints in management theories. Academy of Management Executive. 7(1), 81-94.

Kaifi, B. \& Noori, S. (2011). Organizational behavior: a study on managers, employees and teams. Journal of Management Policy and Practice, 12(1), 88-97.

Laurent, A. (1981). Matrix Organizations and Latin Cultures. International Studies of Management and Organization, 10(4), 101-114.

Matko, A. \& Takacs, T. (2017). Examination of the relationship between organizational culture and performance. International Review of Applied Sciences and Engineering, 8(1), 99-105.

Rousseau, D. (1997). Organizational behavior in the new organizational era. Annual Rev. Psychology, $45,515-546$.

Schein, E.H. (1992). Organizational Culture and Leadership. San Francisco: Jossey-Bass Publishers.

Stok, Z. M, Markic, M., Bertoncelj, A. \& Mesko, M. (2010). Elements of organizational culture leading to business excellence. Zbornik Radova Ekonomskog Fakultet au Rijeci. 28(2), 303-318.

Sull, D., Sull, C. \& Chamberlain, A. (2019, June 24). Measuring culture in leading companies. Introducing the MIT SMR/Glassdoor Culture 500. MIT Sloan Management Review and Glassdoor. Retrieved May 15, 2020, from https://sloanreview.mit.edu/projects/measuring-culture-in-leadingcompanies/.

Szczepanska-Woszczyna, K. (2015). Leadership and organizational culture as the normative influence of top management on employee's behavior in the innovative process. Procedia Economics and Finance, 34, $396-402$.

Ouchi, W. G. (1981). Theory Z: How American Business Can Meet the Japanese Challenge. Business Horizons, 24(6), 82-83.

Yesil, S. \& Kaya, A. (2013). The effect of organizational culture on firm financial performance: evidence from a developing country. Procedia Social and behavioral sciences, 81, 428-437.

Hofstede Insights. (2018). Report on the Organizational culture. Helsinki. 